\title{
AN ACADEMIC WRITING NEEDS ANALYSIS OF CZECH UNIVERSITY GRADUATE STUDENTS
}

\author{
Renata Jančaříková \\ Renata Povolná \\ Olga Dontcheva-Navratilova \\ Světlana Hanušová \\ Martin Němec
}

\begin{abstract}
The present paper presents the results of a needs analysis conducted among Czech students involved in a Master's degree programme English Language Teacher Education. The aim was to identify their academic writing needs on the basis of a needs analysis questionnaire and a linguistic analysis of their written discourse in order to find out whether there are divergences between their 'wants' and 'lacks' (Hutchinson \& Waters 1987). The results indicate that the students' previous tuition at Bachelor's level focused primarily on lexico-grammatical features of academic style such as text organizing devices, academic vocabulary, grammatical structures and citation styles. However, other areas essential to writing a successful Master's thesis, such as evaluation and interpretation of results, conveying personal viewpoints and communicating with the reader or acknowledging research limitations, were ascribed a somewhat lower importance by the students, suggesting the existence of a divergence between the students' 'wants' and 'lacks'. The findings concerning the students' perception of the writing process also concur with the finding of the authors' previous research (Dontcheva et al. 2020) into the Theme zone in Czech students' Master's theses, which has indicated that Czech Master's students tend to overuse textual Themes expressed by linkers and underuse interpersonal Themes realised by stance devices.
\end{abstract}

\section{Keywords}

needs analysis, academic writing, EAP, thesis writing, questionnaire, Theme zone, Master's thesis

\section{Introduction}

Writing at university level involves a number of various types of written assignments that students may not have sufficient experience with, as the focus of writing within their previous education lies mainly in general English writing skills. Apart from acquainting students with the specificities of academic texts, one of the main tasks of writing instructors is to guide and assist students systematically throughout the writing process and help them acquire and/or 
develop the skills necessary for successful writing performance at tertiary level (Bailey 2006, Paltridge \& Starfield 2007, Creme \& Lea 2008). Writing a thesis to complete one's university studies can be described as a difficult, long and challenging journey the goal of which is an elaborate and well-argued compact whole demonstrating the student's knowledge and understanding of the topic, the ability to formulate research questions, design and perform a meaningful analysis, derive conceptual conclusions and indicate possibilities for further research (Wisker 2012). Thesis writing thus represents a highly complex process that, apart from adequate linguistic competence, requires an appropriate knowledge of the genre conventions and an array of skills essential for producing a persuasive high-quality text, such as "critical thinking, reflective writing, reasoned analysis, problem solving and information literacy” (Gunn et al. 2011: 1).

Since the Master's thesis is the most sophisticated piece of academic writing that university students are expected to produce (Swales 2004: 99), the acquisition of the genre's rhetorical conventions should be at the heart of an 'English for Academic Purposes' (EAP) writing course for graduate students. The design of such a course has to stem from the 'situation' and the needs of students (Hamp-Lyons 2001). However, there is a paucity of research into the academic writing needs of Czech graduate university students. This study undertakes to fill this gap by exploring the needs of graduate students involved in the Master's degree programme English Language Teacher Education (ELTE) at the Faculty of Education of Masaryk University on the basis of a needs analysis questionnaire and a linguistic analysis of the written discourse of the students.

\section{Academic writing}

The ability to write academic texts in English does not simply derive from a good level of language proficiency (Paltridge et al. 2009) or the ability to write various general types of text. It would also be wrong to assume that native speakers are automatically good academic writers. As Schmied (2013:20) points out, "since there are no native speakers, let alone writers, of academic English, it has to be learnt by everybody [...]". Goodson (2017: 73) points out that:

Academic writing in English behaves almost as a dialect - a second English, if you will. [...] Academic authors must master the complex structure and the rules the dialect contains. In this sense, mastering academic writing in English is almost akin to mastering English as a second language (ESL). Here, native English speakers and ESL writers are more or less at the same level: they both have to face a learning curve when it comes to their academic writing. 
Research into the teaching of academic writing has thus been gaining in importance in order to reflect the increasing need for systematic and effective academic writing instruction at tertiary level, and it emphasises that "the teaching of academic writing needs to focus on more than just language-related issues" (Paltridge et al. 2009). Hyland's (1997) seminal study, in which a large-scale survey was undertaken among Hong Kong tertiary students to advocate the necessity for EAP at Hong Kong universities, laid the foundation for research both in the Hong Kong tertiary landscape (e.g. Evans \& Green 2007, Crosthwaite $\&$ Jiang 2017) and worldwide. Since then the range of research into academic writing has extended and has taken a number of more concrete tracks. Some researchers explore and compare native and non-native writers' performance, e.g. the use of concessives and contrastives in L1 and L2 student writing (Wagner 2011), lexical bundles indicating authorial presence by novice Czech and German academic writers (Dontcheva-Navratilova 2013), or sentence adverbials in academic texts by native and non-native writers (Vogel 2013). Others focus directly on the teaching and methodology of academic writing at universities, investigating, for example, students' writing from sources (Cumming et al. 2016), the potential of online writing for the development of writing skills (Ismail et al. 2012), using corpora to teach rhetoric in writing courses (Poole 2016) or teaching academic writing through data-driven learning (Chen et al. 2019). Another area of research crucial for the teaching of academic writing at university level is the design of writing courses, a fundamental component of which is a needs analysis. For example, Huang (2010) investigated students' writing needs in order to define the aims and range of support to be provided by a new academic language support centre at a Canadian university and Link (2018) performed a large needs survey prior to creating a dissertation writing workshop at an American university. In the same vein, the present study aims to identify Czech university students' writing needs in order to help them to write their Master's theses, which requires not only producing a well-formed argumentative academic text but also accommodating to the Anglophone academic writing conventions that differ from their L1 academic literacy.

\section{Needs analysis and academic writing}

Recent research has suggested that EAP courses, unlike EFL courses, start from particular learners and their specific needs, and it has emphasised the importance of performing a needs analysis prior to designing an EAP course (e.g. Flowerdew \& Peacock 2001, Huang 2010, Link 2018). As Hamp-Lyons (2001: 127) concludes: 
Needs analysis leads to the specification of objectives for a course or a set of courses and to an assessment of the available resources and constraints to be borne in mind, which in turn lead to the syllabus(es) and methodology.

A number of researchers have propounded the notion that the needs as seen by teachers and learners may not always correlate - students may not always realise which particular skills they need to develop while their instructors may have wrong or just rather general assumptions about what the students can and cannot do and need to focus on (Huang 2010). With regards to ESP courses, Hutchinson and Waters (1987) identify two principal types of needs termed 'target needs' and 'learning needs', the former being "what the learner needs to do in the target situation" and the latter "what the learner needs to do in order to learn" (ibid.: 54). The 'target needs' encompass three basic types of need; (1) 'necessities', i.e. needs that arise from the target situation, (2) 'lacks', i.e. which of the required skills the students lack and which need to be taught, and (3) 'wants', i.e. what the learners themselves consider to be the lacks that they need to work on. Although 'necessities' and 'lacks' can be defined as objective needs, it is assumed that students themselves have some awareness of the target situation ('necessities') and their own views of their 'lacks', which then transform into their own perception of what they think they need to improve, i.e. 'wants' (Hutchinson \& Waters 1987: 55-58). The 'learning needs' are in fact psychological needs directly linked with the learning situation, i.e. how we proceed and make learning happen to achieve the desired outcomes. Other researchers provide alternative perspectives, for example, Berwick (1989) points out the difference between 'felt needs' and 'perceived needs', i.e. "a personal, inside perspective and a more objective view of the professional learner and his or her professional context for learning" (Huhta et al. 2013: 11). Similarly, Brindley (1989) points to the distinction between 'objective' and 'subjective' needs, i.e. needs as seen from the outside perspective and personal, inner needs as a particular individual feels them, and further proposes distinguishing between 'process-oriented' and 'product-oriented' needs, i.e. the learning process vs. the desired outcomes. In relation to EAP and academic writing courses in particular, the unifying proposition of the above mentioned approaches is that a needs analysis can provide a complex view of all types of students' needs from multiple perspectives.

Writing tuition should thus take into account (1) the 'necessities' following from the target situation, (2) the needs which the students themselves consider their weaknesses (i.e. their 'wants') and (3) the needs displayed in the students' own writing (i.e. their 'lacks'), which they may not always realise and which 
point to the skills that the writing tuition should focus on. The potential of a needs analysis to create a complete picture of both the learning and teaching situation makes it particularly important not only in terms of syllabus design as such but also in terms of informative value for the writing course instructors who thus gain specific knowledge of the students' needs, skills and their attitudes to writing.

The research questions that this study undertakes to answer are:

1) What are the perceived academic writing needs of the students (i.e. their 'wants')?

2) What are the students' 'lacks' as displayed in their academic texts?

3) Is there a divergence between the students' 'wants' and 'lacks'?

\section{Data and method}

The study presents the results of a needs analysis which is part of a larger project on the research and teaching of academic writing at tertiary level from an intercultural perspective. The academic writing needs analysis was undertaken among the students of the ELTE study programme at the Faculty of Education of Masaryk University. Since an efficient needs analysis requires a number of mutually connected analytical methods (Long 2005), as multiple sources "add breadth and depth to an analysis" (ibid.: 63), the current investigation comprises a questionnaire filled in by the ELTE study programme students aiming at identifying the students' 'wants', and a linguistic analysis of the students' written performance aiming at identifying their 'lacks'. The combination of these two analytical methods allows us to find out whether there are divergences between what the students perceive as their needs and the needs that their writing performance reveals.

Writing instruction at Czech universities is largely provided in writing courses that are part of standard Bachelor's and Master's study programmes. The Bachelor's programme typically includes a one-semester academic writing course focusing on general writing skills, which introduces students to the basics of academic style, the range of and differences between various citation styles, or the conventions of writing from sources, text organisation, structural complexity, academic vocabulary, coherence and convincing argumentation. Nevertheless, our experience and previous research (Dontcheva-Navratilova et al. 2013) show that while it certainly raises students' awareness of these issues, such a course cannot provide them with extensive input and contextualized practice. Another factor to take into account is students' non-native speaker status, as they have more experience of writing in Czech than in English, which may result in a transfer of L1 writing habits to their writing in English (cf. Paltridge \& Starfield 
2007). When entering the Master's study programme, students already have the experience of writing a Bachelor's thesis - the first academic text of extensive scope and length that they produce. However, the knowledge and experience students gained previously may not be sufficient for producing a Master's thesis of the expected quality as they are supposed to do more than just "re-state facts" (Paltridge et al. 2009); they have to demonstrate their knowledge about the topic, adopt a critical approach to existing knowledge and research findings, pose questions, argue their points, etc. (ibid.). Bearing this in mind, this study explores students' academic writing needs by comparing the students' perception of their academic writing skills to the results of a linguistic analysis of their written performance in order to inform the design of a graduate-level course aimed at discipline-specific writing.

In agreement with common practice in needs analysis research (Brown \& Rogers 2002, Dörney 2010, Hyland 2016), a questionnaire was designed to explore the students' background, their previous writing tuition, their attitudes to writing and their expectations of a future writing course. The questionnaire was inspired by similar instruments used in published studies (e.g. Xudong et al. 2014, Chitez et al. 2015, Link 2018). The questionnaire was distributed among 84 ELTE study programme students, out of which 13 had to be excluded as they were non-native speakers of Czech, since the research was aimed at Czech students only. The total number of students who filled in the questionnaire was 67 , i.e. the return rate was 94 per cent.

The questionnaire was divided into three sections. Section One included demographic information, i.e. type of programme, year of study, age, gender and mother tongue. Section Two consisted of five questions concerning the students' prior writing experience, i.e. the types and number of writing tasks performed in the past, the amount and type of instruction received previously, stages and areas of the writing process facilitated by their teachers/instructors (e.g. brainstorming, drafting, citing sources carefully, avoiding plagiarism), previously taken writing courses, etc. Section Three comprised nine questions focusing on the students' knowledge of academic writing style, their 'wants' in Hutchinson and Waters' terms (i.e. what they feel they need to work on) in relation to their strengths and weaknesses and the importance of various stages of thesis writing as seen by the students. To obtain the desired data, open-ended questions (e.g. If you are familiar with the academic writing style, how would you define it?) and a number of rating scales were used, for example, Likert scales for students' own assessment of their strengths and weaknesses in academic writing (e.g. grammar, academic vocabulary, text organization) and for the questionnaire items concerned with (1) individual features of academic writing (e.g. staying on topic, 
using background knowledge to support one's ideas, refining arguments), and (2) the students' perception of the importance of various aspects of thesis writing (e.g. identifying the intended audience, taking an evaluative stance towards existing literature, persuading readers of the credibility of one's own work). The last section of the questionnaire also included an open-ended question targeting the students' expectations of the academic writing course.

The linguistic analysis of the students' written discourse is informed by our previous investigation (Dontcheva-Navratilova et al. 2020) carried out on a specialised learner corpus comprising 48 Master's theses written by Czech university students in the period 2010-2018 representing the following disciplines: linguistics, literature and cultural studies, and ELT methodology. The Master's theses corpus (MT corpus), totalling one million words after all the texts were cleaned so as to exclude all citations, examples and tables, was built by means of the software SketchEngine (Kilgarriff et al. 2004), which was also used in the analysis. In addition, students' texts produced in controlled conditions (pre-test, written assignments and post-tests) were subjected to manual analysis to contextualise the corpus analysis results.

\section{Results}

\subsection{Questionnaire results: Prior writing experience}

The Prior writing experience section of the questionnaire maps the students' writing experience, in particular what kind of writing they did previously, what instructions, if any, on the writing process they received from their teachers, whether they took part in a course in (general) writing and what the subject area of their Bachelor's theses was. The information gathered is important for identifying the students' current needs and expectations, which should be reflected in academic writing courses aimed at providing genre-based instruction to students preparing to write their Master's theses (cf. Hyland 2004).

The students who participated in the investigation had previous experience in writing different genres, although mostly restricted to general writing activities. In this and several other questions students gave multiple answers, which is why the results do not correspond to the total number of 67 respondents. The most frequently experienced genres are the advantages and disadvantages essay and the literary analysis essay (68\% and $43 \%$ of the students respectively have written such essays more than 6 times), while the argumentative essay (24\%), the contrast and comparison essay (21\%) and the seminar paper reporting research results $(17 \%)$ seem to be less familiar forms. However, reporting research and 
presenting argumentation are key dimensions of academic writing which novice writers are usually not very aware of (Schmied 2011).

The results of the questionnaire also indicate that 83 per cent of the respondents wrote their Bachelor's theses in English, which suggests that they have some awareness of Anglophone academic writing style conventions.

As to instructions and advice received prior to writing (Figure 1), many respondents reported receiving instructions on organization (66\%), argumentation (59\%), and language and style (41\%). When compared to Dontcheva-Navratilova and Povolná's (2014) study, this testifies that the skills of logical reasoning, justifying beliefs and drawing conclusions based on facts and evidence are getting more attention in university students' tuition. Only eight per cent of the students received instructions on other issues, such as the expected word-count of the text, and only one reported being advised on recommended citation styles and the difference between primary and secondary sources. Finally, three per cent of the respondents did not receive any instructions at all, not even on grammatical issues and referencing, which are usually addressed in manuals on academic writing (Hamp-Lyons \& Heasley 2006, Bennett 2009).

\section{Before writing an essay (of any sort) did you get instructions/advice from} your teacher/instructor concerning the essay's:

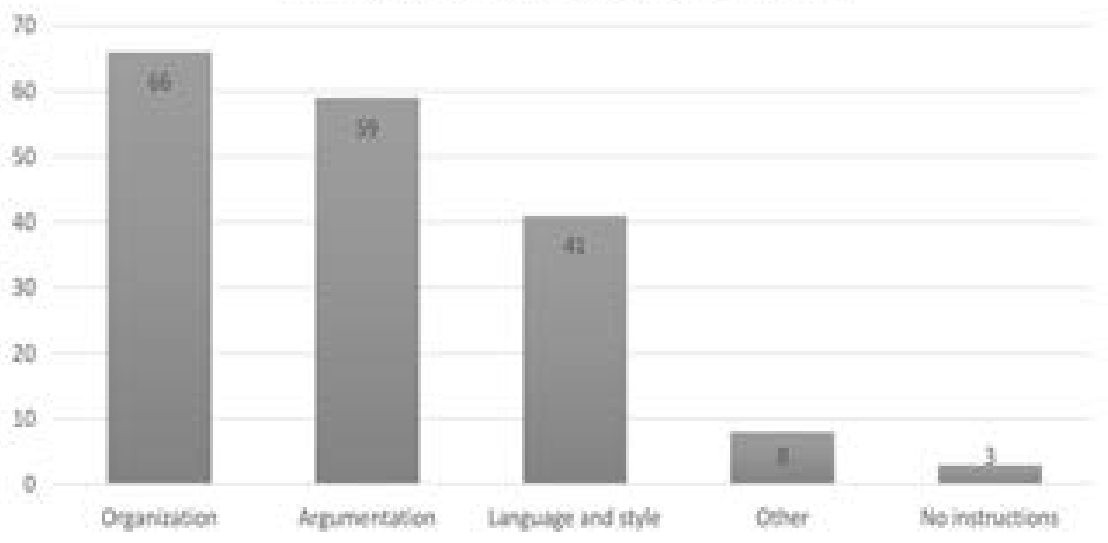

Figure 1: Instructions before writing an essay

Regarding instructions on the writing process prior to writing (Figure 2), the majority of the students were advised to write drafts (48) and do brainstorming (47). Forty-six were recommended to do some research and try to understand the 
format of the given written assignment. A slightly lower number (42) reported that they had been advised to cite sources carefully and the lowest number (36) was instructed to revise and edit their essays. These results prove that the majority of the respondents had a chance to learn at least something about the five important stages of the writing process, i.e. brainstorming, preparing, drafting, revising and proofreading (cf. Hamp-Lyons \& Heasley 2006), in preparation for the writing of a Master's thesis.

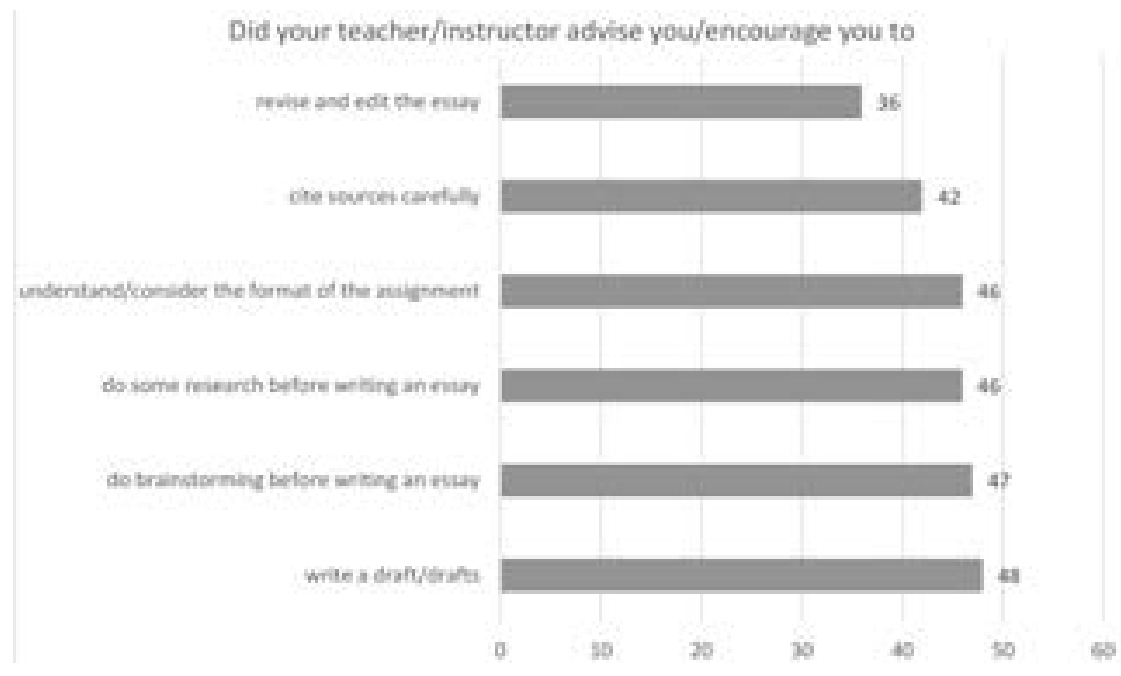

Figure 2: Instructions on the writing process

Finally, experience with model essays regarded as a key component of teaching writing skills (Link 2018) was acknowledged by 58 per cent of the students. However, more than 68 per cent of the students did not attend any English writing course (e.g. creative, business or general), mostly as a result of commitments in other subjects, since half of the respondents followed a double major programme.

\subsection{Questionnaire results: Academic writing - needs and expectations}

Section Three of the questionnaire, labelled Academic writing - needs and expectations, comprises questions concerning the students' experience in academic writing and knowledge of some relevant academic style issues, such as citing, paraphrasing and plagiarism. This part also focuses on discovering the students' awareness, knowledge and expectations associated with academic writing and the genre of the Master's thesis. 
The results show that almost 50 per cent of the respondents participated in an academic writing course at the English department of the Faculty of Education, while the other half took part in various courses at other faculties of Masaryk University or a different university, since some of the respondents gained their Bachelor's degrees at other universities.

More than half of the respondents (55\%) believed they knew the 'academic writing style' and its typical features, fewer (32\%) claimed they had heard the term and 14 per cent admitted they were not familiar with it at all. Those who believed they were familiar with academic writing mostly emphasised its objectivity (e.g. the use of the passive voice, avoidance of personal structures and first person pronouns), coherence and the prominence of cohesive devices (e.g. conjuncts and conjunctions), i.e. language means mostly used in the Theme zone and performing the function of textual Themes, which is a key aspect of our corpus-based investigation carried out on the MT corpus (Dontcheva-Navratilova et al. 2020). The respondents also mentioned academic and formal vocabulary, avoidance of personal pronouns, phrasal verbs, contractions and informal words. Of the more specific features of academic language, they pointed out appropriate citations, lists of sources, comparison of APA and MLA styles with Czech academic conventions, argumentation based on sources and paraphrases and avoidance of plagiarism. However, apart from mentioning the differences in citation styles, the students showed little awareness of the differences between Anglophone and Czech academic writing styles, such as the use of personal and impersonal constructions, and resources for building up argumentation (e.g. Čmejrková \& Daneš 1997, Čmejrková et al. 1999, Chamonikolasová 2005, Dontcheva-Navratilova 2012).

The questions targeting the students' strengths and weaknesses in academic writing in English (the latter pointing to their 'wants' in Hutchinson \& Waters' terms) are based on Likert scales (Figure 3). The respondents perceived their own strengths and weaknesses as mostly average ( 2.5 points). A slightly higher ranking (2.8) was attributed only to paraphrasing information from various sources, which is also one of the features associated with the academic writing style. Summarising information from various sources and text organization are still neither the students' weakness, nor their strength, which points to the necessity of including them in further tuition. Slightly lower results were reported for topic continuity (2.3), i.e. an academic style feature that can also be enhanced by an adequate expression of textual Themes studied in our previous investigation (cf. Dontcheva-Navratilova et al. 2020). Grammar (2.1) and academic vocabulary (2) were still perceived by students rather as weaknesses, although both are traditionally listed among features typical of academic style 
(Bennett 2009). Topic continuity together with grammar and academic vocabulary (see Figure 3) were thus identified as students' 'wants', i.e. the features that they feel they need to improve to meet the thesis requirements. Interestingly, only one respondent considered grammar his/her strength and only two respondents considered academic vocabulary as their strong point. In general, the students did not consider any of the features their particular strength, as none of the features reached a result higher than 2.8 .

\section{What do you consider to be your strengths and weaknesses in academic writing in English? (scale 1 - weak to 5 -strong)}

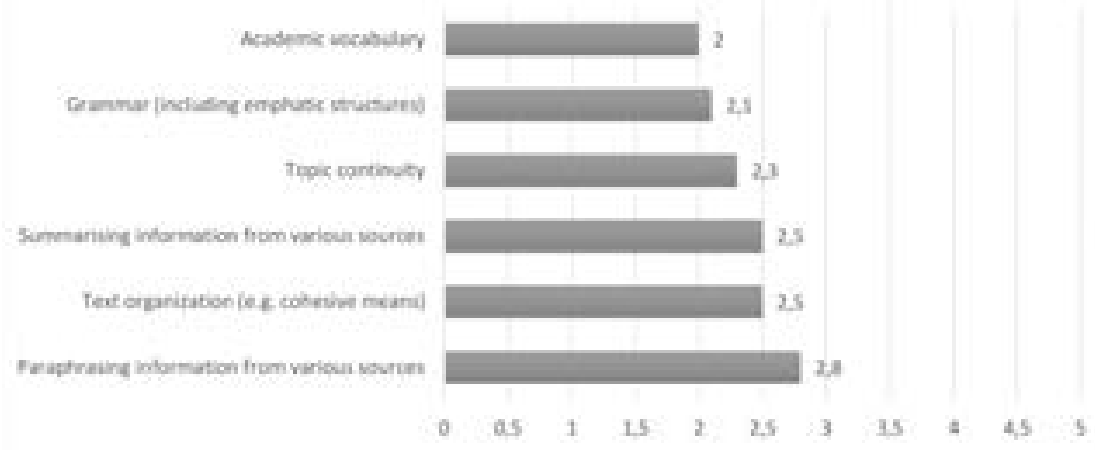

Figure 3: Strengths and weaknesses in academic writing in English

The importance attributed to different aspects of academic writing in relation to course and degree completion was explored on the basis of a five-point scale ranging from Not important at all (value 1) to Extremely important (value 5). As course and degree completion are closely related, we decided to process the results together. To reduce dimensionality, we decided to group the target aspects of academic writing logically into five factors and verified the internal consistency of the factors by Cronbach alpha $(\alpha)$ test. The values of Cronbach alpha for four of the factors, i.e. Organization of the text and flow of the argument, Evaluation, Meta-awareness and Linguistic aspects, were satisfactory, ranging from 0.61 to 0.75 ; however, the Reporting results and relating them to previous research factor yielded a lower value and thus the aspects originally aggregated in it are analysed separately.

The evaluations of the respondents are relatively high for all factors and individual aspects of academic writing, which indicates the students understood all of them as rather important for the development of their writing competence 
and thus to course and degree completion. The factor with the highest average scores is Organization of the text and flow of the argument $(\varnothing=4.37)$, which indicates that the respondents ascribe the highest level of importance to the items aggregated in this factor. The statements (ordered from the most to the least important) included: 'introducing the research purpose' $(\varnothing=4.48)$, 'organising writing in order to convey major and supporting ideas' $(\varnothing=4.42)$, 'using relevant reasons and examples to support a position or idea' $(\varnothing=4.39)$, 'compiling findings into a clearly connected argument' $(\varnothing=4.35)$ and 'writing to the topic and staying on topic without digressions' $(\varnothing=4.21)$. It is worth noting that between 88 and 91 per cent of respondents marked each of these features as extremely or very important while practically nobody assigned them lesser importance.

Reporting results and relating them to previous research was evaluated as equally important as Organization of the text and flow of the argument, although the slightly lower average scores indicate that the importance of these aspects of academic writing was perceived as slightly lower. The individual statements, which are not aggregated into a meaningful factor, comprise: 'identify an area that needs to be addressed by research' $(\varnothing=4.28)$, 'demonstrate my knowledge of the research topic' $(\varnothing=4.20)$, 'transform data into results' $(\varnothing=4.18)$ and 'effectively summarise and paraphrase the works and words of others' $(\varnothing=4.14)$. These results suggest that students are particularly concerned with text clarity and organization, i.e. they prioritise content-oriented aspects of academic writing rather than rhetorical strategies and interactional resources that enhance academic persuasion.

Linguistic aspects with the average score of 3.95 refer to 'familiarity with the conventional structure of a thesis' $(\varnothing=4.35)$, 'demonstrating a command of standard written English, including grammar, phrasing, effective sentence structure, spelling and punctuation' $(\varnothing=4.27$, i.e. $90 \%$ of the respondents marked this feature as extremely or very important and not a single respondent marked it as unimportant), 'using appropriate transitions to connect ideas, information and text components' $(\varnothing=3.97)$, 'producing a written text of an expected length appropriate to the topic' $(\varnothing=3.82)$, and 'demonstrating facility with a range of vocabulary appropriate to the topic' $(\varnothing=3.73)$. The scores indicate that the respondents perceive the Linguistic aspects as very important, even if not equal with Organization of the text and flow of the argument, which may stem from the importance attributed to these factors in the Bachelor's degree writing course that many of the students have attended.

The factor called Evaluation yielded the second lowest average score $(\varnothing=3.67)$, which indicates that this aspect of academic writing was perceived by the respondents as less important than the two previously discussed factors. 
Out of the four aspects in this factor, 'communicating one's own understanding and interpretation of the results' $(\varnothing=3.94)$ yielded the highest average score and was considered as extremely or very important by 73 per cent of respondents. The statements 'take an evaluative stance towards existing literature' $(\varnothing=3.68)$ and 'provide an extended analysis of your results through an interpretative and evaluative angle' $(\varnothing=3.60)$ are seen as less central to academic writing as the responses are generally evenly spread on the scale between 'very important' and 'slightly important' with a peak in the 'very important' and 'moderately important' levels. 'Conveying personal viewpoints and evaluating previous and own research to construct arguments' $(\varnothing=3.46)$ was seen as important by 55 per cent of the students, while ten students (i.e. 15\%) considered this point as slightly important or not important at all. The overall results for the Evaluation factor seem to suggest that students do not have sufficient awareness of the importance of evaluation in academic writing and are likely to lack the skills necessary for the expression of stance, and as the last factor below indicates, of engagement with the reader.

The lowest average score $(\varnothing=3.62)$ was identified for the factor called Metaawareness, which reflects the writer's awareness of the audience. This factor includes eight aspects (ordered from the most to the least important): 'show the value of your research' $(\varnothing=3.87)$, 'explain steps taken in my study' $(\varnothing=3.80)$, 'indicate how the findings add to existing knowledge in the field' $(\varnothing=3.73)$, 'persuade readers of the credibility of your work' $(\varnothing=3.66)$, 'identify the intended audience/readers and their expectations' $(\varnothing=3.59)$, 'acknowledge limitations of your work' $(\varnothing=3.50)$, 'show awareness of audience needs and write to a specific audience' $(\varnothing=3.39)$ and 'expand the meaning of findings outside my own research' $(\varnothing=3.35)$. Out of the five factors discussed, the results for Meta-awareness show the most variation. The individual aspects are mostly marked as important or very important but, contrary to the first factor discussed, very few respondents mark them as extremely important; for example, only three students consider showing awareness of audience needs and writing to a specific audience as extremely important while nine students consider it slightly important, and identifying the intended audience and their expectations is marked as extremely important by six students only. The most varied answers concern expanding the meaning of findings outside one's own research, which 42 per cent of respondents consider as very important, 39 per cent as important and 19 per cent see it as only slightly important. The underestimation of the meta-awareness dimension seems to reflect the novice status of Czech graduate students who need more extensive exposure to expert academic texts and writing practice in order to enhance their academic writing competence in English. 
We can conclude that in the course of the needs analysis the respondents did not fully appreciate the importance of showing awareness of the audience and perceived this as less important than other aspects of academic writing. The respondents seemed to ascribe higher importance to the factors that they were more familiar with (Organization of the text and flow of the argument and Linguistic aspects) and that are more general and more directly aimed at the content. The remaining two factors (Evaluation and especially Meta-awareness) were probably seen as less directly connected with academic writing. Drawing on Howell (1979, 1982), Huang (2010) speaks about the difficulty the students may have when they are to identify challenges that are in the zone of unconscious incompetence. It is then the instructor's task "to guide the students toward discovering and exploring skills that lie within the zone of unconscious incompetence" (ibid.: 533). In this light, our results show that the respondents' needs are primarily associated with developing their skills related to expressing stance and engaging with the audience, i.e. the interpersonal dimension of academic writing, which generally shows considerable variation along the learner-native and novice-expert dimensions (cf. Gilquin et al. 2007, Dontcheva-Navratilova 2014, Carrió-Pastor 2020).

Finally, in the last open-ended item in the questionnaire the respondents were asked to list the aspects of academic writing that they would expect to improve in a graduate academic writing course. Here again, the most frequent areas selected were tuition in academic vocabulary and grammar (e.g. distinguishing formal vs. informal means, avoiding repetition), topic continuity and text organization, appropriate ways of introducing research goals, identifying and supporting ideas, positions and arguments, sticking to the topic without digressions, transforming data into results and conclusions, while persuading readers of the credibility of the author and his/her work were mentioned only scarcely. This concurs with the results of the questionnaire items exploring the students' perception of academic writing features. These suggest that while the respondents realise the importance of various academic style features such as logical argumentation, adequate interpretation of results and drawing conclusions based on data and results, they are not fully aware of the need to express authorial stance and engagement with the reader, which thus may be regarded as pertaining to students' unconscious incompetence and should be the focus of graduate academic writing courses.

\section{Linguistic analysis of students' written discourse}

The aim of the linguistic analysis of students' written discourse was to find out to what extent the students' perception of their academic writing skills corresponds to their academic writing performance. The results of the analysis 
are expected to identify the areas that writing tuition at higher levels should focus on in order to enhance their academic writing competence.

Our corpus-based research carried out on the MT corpus focused on the Theme zone, i.e. the initial part of the sentence which "codes relational-semantic 'aboutness' syntactically" (Fetzer 2008), aimed at exploring Theme patterning, as it has a strong potential for enhancing discourse coherence. The investigation studied the frequency of occurrence and realisations of the three types of Themes conveying the primary language functions (ideational, textual and interpersonal, Halliday \& Matthiessen 2014): (i) topical Themes communicating main ideas and concepts, (ii) textual Themes indicating logical relations, and (iii) interpersonal Themes positioning the writer towards the content conveyed and the reader (Eggins 2004, Hannay 2007, Thompson 2014). The results of our investigation (Dontcheva-Navratilova et al. 2020) indicate that although Czech students tend to abide by the formality, explicitness and clarity requirements in academic discourse and have an awareness of the crucial role that the Theme zone plays in the build-up of discourse coherence, they show a strong tendency to use only simple and two-component Theme patterns (Textual + Topical, and Interpersonal + Topical), overuse textual Themes and underuse interpersonal Themes.

These results confirm the questionnaire findings and point to some tendencies in Czech students' academic discourse in crucial areas such as text organization or stance expression. Our findings have proved that topic continuity is one of the students' 'lacks', as we have identified a relatively limited range of coherence-building devices employed in the Master's theses. The analysis of the MT corpus (Dontcheva-Navratilova et al. 2020) has revealed that Czech students' discourse displays typical features of learner discourse characterised by overuse or underuse of topical and interpersonal Themes (e.g. Ädel 2006, Gao 2016, Wei 2016, Chang \& Lee 2019). Table 1 shows the normalised frequency of occurrence of textual and interpersonal Themes in the MT corpus as compared to the results of the analysis of textual and interpersonal Themes in a corpus of essays by British students (BAWE-LLCM) (Dontcheva-Navratilova et al. 2020) and in a corpus of research articles by Anglophone scholars in the same soft fields (Hůlková et al. 2019) (all corpora comprise texts evenly representing the fields of linguistics, literature, culture and ELT methodology, i.e. LLCM). As Table 1 indicates, both Czech and Anglophone students tend to overuse textual Themes as compared to expert writers' discourse, which seems to indicate variation along the level of the expertise dimension; however, the lower use of interpersonal Themes in the texts of Czech students appears to be also affected by their linguacultural background. Czech students tend to heavily rely on text organizing devices, i.e. textual Themes realised mainly by conjunctive 
adjuncts and conjunctions (e.g. the enhancing adjuncts therefore and thus, or the extending ones such as moreover and on the other hand; the most common conjunction used is and) instead of expressing relations on a clausal or textual level. Also, the students' academic writing displays tendencies to avoid personal structures reflected in the relatively scarce use of interpersonal Themes (e.g. those expressing 'opinion' such as I believe or I think) and structures conveying their own stance towards the content to express, for example, 'probability' (perhaps, it is possible), 'persuasion' (indeed, in fact) or 'obviousness' (clearly, certainly). These are employed much less frequently than textual Themes, which, when realised as conjunctive adjuncts, tend to be frequently overused by Master's degree students (cf. e.g. Povolná 2010, 2012).

\begin{tabular}{|l|r|r|r|}
\hline Type of Theme & MT corpus & BAWE-LLCM & Anglophone RAs \\
\hline Textual Themes & 16,453 & 16,230 & 10,720 \\
\hline Interpersonal Themes & 1,195 & 2,310 & 2,010 \\
\hline
\end{tabular}

Table 1. Textual and interpersonal Themes in the MT corpus (per 1 million words)

Textual Themes appear to be favoured by students, presumably due to their explicit meaning and natural position at the beginning of a sentence and/or the tutors' emphasis on expected elaborate text organization. This emphasis, however, may be counterproductive as students seem to use these devices excessively, even at the beginning of every or every other sentence within a paragraph while paying little attention to whether the devices used really express the intended relation to the previous idea or text, often resulting in only superficial textual organization.

Interpersonal Themes, which are directly related to the more complex skills of evaluation and interpretation of results and communication with the reader, stating limitations of one's own research as well as expanding the results outside one's own research, occur considerably less frequently, which should not be interpreted just as the students' inability to express these relations. The low occurrence of interpersonal meanings may simply result from their previous tuition which encouraged impersonal expression. The students therefore may not feel the need to express stance, because they believe it is not expected, or simply because they may not feel erudite enough to engage with or even challenge the ideas of scholars whose works they discuss to contextualise their own research.

These tendencies are illustrated by the sample discourse editing task completed by students during their academic writing course. Within the discourse editing 
task students edit a set of text chunks without changing their chronological order so as to construct a coherent and well-formed text (cf. Fetzer 2018). The aim of this activity is to enhance students' ability to exploit the potential of the Theme zone for constructing discourse coherence.

The Discourse editing task - Summary focuses on writing a summary as a component of the conclusion section of a thesis. The sample text represents a typical example of the way the majority of the students involved in the academic writing course related the set of text chunks to form a coherent summary. As the example indicates, the student has used the twelve chunks to construct only ten sentences (combining just the two matrix clauses (2) and (5) with one of the clausal objects (3) and (6) available in the set), thus failing to notice the possibility of grouping the chunks into more complex condensed and logically related units. The student has successfully identified the three main issues, which are indicated by the listing conjunctives firstly, secondly and thirdly, thus contributing to the global coherence of the text. However, the logical relations between the chunks within theme one and two are somewhat problematic, as (4) is not necessarily a consequence of (3) (it might be rather seen as a concurrent and probably contrastive phenomenon), and (6) and (7) are better seen as related temporally rather than by a contrast relation. In addition, the time reference (in the 1960s and 1970s) is unnecessarily repeated in two adjacent clauses. It is obvious that the main device that the student employs to construct coherence at the local level of the text is conjunctives indicating logical relations (highlighted in bold in the text sample) as practically each sentence begins with a textual Theme. The variety of linking adverbials used suggests that the student has successfully acquired this aspect of academic writing and uses it extensively to create a somewhat superficial appearance of academic style (cf. Hawes \& Thomas 2012); however, the potential of alternative resources, such as adverbial non-finite clauses or stance and engagement devices is not exploited at all. The analysis of the Discourse editing task-Summary sample confirms the findings of the investigation into Theme patterning in the MT corpus indicating an overuse of textual Themes. It is also relevant to note that the student has not added any interpersonal Themes to express authorial stance or engagement with the audience. It is likely that the student has considered the use of the personal form we (we have shown, we demonstrate) available in the text as sufficient to express authorial stance; however, the avoidance of interpersonal Themes may also be seen as concurring with the lower awareness of the importance of the interpersonal dimension of academic discourse among Czech students and the lower rate of interpersonal Themes in the MT corpus (Table 1). 


\section{Discourse editing task - Summary}

1) this article develops three themes

2) we have shown that

3) local housing policy was channelled by government initiatives

4) local political and civic values gave rise to a policy orientation that had a significant influence on the lives and perceptions of public sector tenants

5) we demonstrate that

6) the tenacious hold of civic and political values contributed to the Labour Party's political difficulties by making it resistant to change in the 1960s and 1970s

7) in the 1960s and $1970 \mathrm{~s}$ a shift in approach was necessary to manage changing circumstances

8) we explore the impact of a constantly reformulated local discursive and cultural tradition

9) we illustrate the explanatory value of a developing but still largely suggestive conceptual approach

10) studying the urban politics of post-war Britain can add to our understanding of the policy process

11) it can provide significant insights into the world of the Labour Party

12) it can focus attention on the role of the consumer in post-war politics

(1) In this article three themes are developed. (2) Firstly, we have shown that housing policy was channelled by government initiatives. (3) Consequently, local political and civic values gave rise to a policy orientation that had a significant influence on the lives and perceptions of public sector tenants. (4) Secondly, we demonstrate that the tenacious hold of civic and political values contributed to the Labour Party's political difficulties by making it resistant to change in the 1960s and 1970s. (5) However, in the 1960s and 1970s a shift in approach was necessary to manage changing circumstances. (6) Thirdly, we explore the impact of a constantly reformulated local discursive and cultural tradition. (7) In particular, we illustrate the explanatory value of a developing but still largely suggestive conceptual approach. (8) To sum up, studying the urban politics of post-war Britain can add to our understanding of the policy process. (9) Additionally, it can provide significant insights into the world of the Labour Party. (10) It can also focus attention on the role of the consumer in post-war politics.

To conclude, taking into account the above mentioned and the traditionally impersonal character of Czech academic writing style (Čmejrková \& Daneš 1997), it seems not surprising that Czech students' English-medium academic discourse shows a tendency to overuse textual Themes (typically conjunctive adjuncts) and underuse interpersonal Themes, which corresponds to their perception of the importance of skills related to the five principal areas of academic writing described above (i.e. Organization of the text and flow of the argument, Reporting results and relating them to previous research, Evaluation, Meta-awareness and Linguistic aspects). An investigation into the students' awareness and approach to thematization reveals that they realise its potential only to a certain extent and need detailed instruction and contextualized practice that would promote deeper understanding of discourse relations across text and achieve more than just superficial coherence. 


\section{Conclusion}

This study has carried out an analysis of the academic writing needs of graduate students involved in the Master's degree programme English Language Teacher Education at the Faculty of Education of Masaryk University on the basis of a needs analysis questionnaire and a linguistic analysis of the written discourse of the students. The results of this investigation indicate that there is a certain divergence between the 'wants' of the students (i.e. the needs within their zone of 'conscious incompetence') and their 'lacks' (i.e. the needs within their zone of 'unconscious incompetence') (Huang 2010: 533). In relation to the present investigation, the zone of the students' unconscious incompetence comprises primarily the expression of authorial stance and engagement with the reader and other advanced argumentative skills. This has been evidenced by the needs analysis questionnaire results indicating that the students consider as very important the skills related to Organization of the text and flow of the argument, Reporting results and relating them to previous research and Linguistic aspects, which receive considerable attention in undergraduate academic writing courses, while the skills related to Evaluation and Meta-awareness seem to be undervalued. Similarly, the findings of the linguistic analysis of the written discourse of the students have shown typical features of learner discourse comprising an overuse of textual Themes (cf. Ädel 2006, Gao 2016) and underuse of interpersonal Themes (cf. Wei 2016, Chang \& Lee 2019) confirming that the students' academic writing skills in the area of writer-reader interaction and persuasive argumentation need to be enhanced. These findings also corroborate with Link's (2018) results indicating that students may have difficulties monitoring their own progress in academic writing, which results in a mismatch between their perceived comfort in writing skills and their academic writing performance.

It should be noted, however, that since "a needs analysis is, by definition, context-dependent and context-specific, taking into account the very different linguistic cultures and the variety of institutional environments" (Huang 2010: 535), the results of our research should not be overgeneralised. We are also aware of the limitations of this survey stemming from the relatively small number of students. Nevertheless, we believe that our results can serve as a starting point for designing an academic writing course aimed to help the current and future students in the Master's degree programmes to become better academic writers. 


\section{Acknowledgement}

This article is an output of the INTER-EXCELLENCE project LTC18015 Výzkum a výuka akademického psani $z$ mezikulturniho hlediska (Researching and teaching academic writing from a cross-cultural perspective) financed by the Ministry of Education, Youth and Sports of the Czech Republic.

This project is related to COST Action CA15221 Advancing effective institutional models towards cohesive teaching, learning, research and writing development.

\section{References}

Ädel, A. (2006) Metadiscourse in L1 and L2 English. Philadelphia: John Benjamins.

Bailey, S. (2006) Academic Writing: A Handbook for International Students. $2^{\text {nd }}$ ed. Abingdon: Routledge.

Bennett, K. (2009) 'English academic style manuals: A survey.' Journal of English for Academic Purposes 8, 43-54.

Berwick, R. (1989) 'Needs assessment in language programming.' In: Johnson, R. K. (ed.) The Second Language Curriculum. Cambridge: Cambridge University Press. 48-62.

Brindley, G. (1989) 'The role of needs analysis in adult ESL programme design.' In: Johnson, R. K. (ed.) The Second Language Curriculum. Cambridge: Cambridge University Press. 63-78.

Brown, J. D. and Rodgers, T. S. (2002) Doing Second Language Research. Oxford: Oxford University Press.

Carrió-Pastor, M-L. (ed.) (2020) Corpus Analysis in Academic Discourse: Discourse Markers, English for Specific Purposes and Learner Corpora. London and New York: Routledge.

Chamonikolasová, J. (2005) 'Comparing the structures of academic texts written in English and Czech.' In: Huttová, M. (ed.) Slovak Studies in English 1. Bratislava: Univerzita Komenského. 77-84.

Chang, P. and Lee, M. (2019) 'Exploring textual and interpersonal themes in the expository essays of college students of different linguistic backgrounds.' English for Specific Purposes 54, 75-90.

Chen, M., Flowerdew, J. and Anthony, L. (2019) 'Introducing in-service English language teachers to data-driven learning for academic writing.' System 87, Article 102148.

Chitez, M., Kruse, O. and Castelló, M. (2015) The European Writing Survey (EUWRIT): Background, Structure, Implementation, and Some Results. (Working Papers in Applied Linguistics 9). Winterthur: ZHAW Zurich University of Applied Sciences.

Creme, P. and Lea, M. R. (2008) Writing at University. A Guide for Students. $3^{\text {rd }}$ ed. Maidenhead: Open University Press.

Crosthwaite, P. and Jiang, K. (2017) 'Does EAP affect written L2 academic stance? A longitudinal learner corpus study.' System 69, 92-107. 


\section{Renata Jančaňíková, Renata Povolná, Olga Dontcheva-Navratilova, Světlana Hanušová, Martin NĚMec}

Cumming, A., Lai, C. and Cho, H. (2016) 'Students' writing from sources for academic purposes: A synthesis of recent research.' Journal of English for Academic Purposes 23, 47-58.

Čmejrková, S. and Daneš, F. (1997) 'Academic writing and cultural identity: The case of Czech academic writing.' In: Duzsak, A. (ed.) Culture and Styles of Academic Discourse. Berlin: Mouton de Gruyter. 40-62.

Čmejrková, S., Daneš, F. and Světlá, J. (1999) Jak napsat odborný text (How to Write a Scientific Text). Prague: Leda.

Dontcheva-Navratilova, O. (2014) 'The changing face of Czech academic discourse.' In: Bennett, K. (ed.) The Semiperiphery of Academic Writing.' Basingstoke: Palgrave Macmillan. 39-61.

Dontcheva-Navratilova, O. (2013) 'Lexical bundles indicating authorial presence: A cross-cultural analysis of novice Czech and German writers' academic discourse.' Discourse and Interaction 6(1), 7-24.

Dontcheva-Navratilova, O. (2012) 'Cross-cultural differences in the construal of authorial voice in the genre of diploma theses.' In: Berkenkotter, C., Bhatia, V. and Gotti, M. (eds) Insights into Academic Genres. Bern: Peter Lang. 301-328.

Dontcheva-Navratilova, O., Jančaříková, R., Hůlková, I. and Schmied, J. (2020) 'Theme choices in Czech university students' English-medium master's theses.' Lingua.

Dontcheva-Navratilova, O., Jančaříková, R. and Povolná, R. (2013) 'Designing courses on academic writing skills at university level.' In: Haase, C. and Schmied, J. (eds) English for Academic Purposes: Practical and Theoretical Approaches. Research in English and Applied Linguistics. REAL Studies 7. Göttingen: Cuvillier Verlag. 123-147.

Dontcheva-Navratilova, O. and Povolná, R. (2014) 'Analysing the development of academic writing skills in English as a lingua franca.' In: Haase, C. and Orlova, N. (eds) ELT Harmony and Diversity. Newcastle upon Tyne: Cambridge Scholars Publishing. 17-54.

Dörney, Z. (2010) Questionnaires in Second Language Research. Construction, Administration, and Processing. $2^{\text {nd }}$ ed. New York and London: Routledge.

Eggins, S. (2004) An Introduction to Systemic Functional Linguistics. New York and London: Continuum.

Evans, S. and Green, C. (2007) 'Why EAP is necessary: A survey of Hong Kong tertiary students.' Journal of English for Academic Purposes 6, 3-17.

Fetzer, A. (2018) 'The coding and signalling of discourse relations in argumentative discourse: Evidence across production format.' In: Gómez-González, M. A. and Mackenzie, J. L. (eds) The Construction of Discourse as Verbal Interaction. Amsterdam: John Benjamins. 13-44.

Fetzer, A. (2008) 'Theme zones in contrast. An analysis of their linguistic realizations in the communicative act of a non-acceptance.' In: Gómez-González, M. A., Mackenzie, J. L. and González Álvarez, E. M. (eds) Languages and Cultures in Contrast and Comparison. Amsterdam: John Benjamins. 3-31.

Flowerdew, J. and Peacock, M. (2001) 'Issues in EAP: Preliminary perspective.' In: Flowerdew, J. and Peacock, M. (eds) Research Perspectives on English for Academic Purposes. Cambridge: Cambridge University Press. 8-24.

Gao, X. (2016) 'A cross-disciplinary corpus-based study on English and Chinese native speakers' use of linking adverbials in academic writing.' Journal of English for Academic Purposes 24, 14-28. 
Gilquin, G., Granger, S. and Paquot, M. (2007) 'Learner corpora: The missing link in EAP pedagogy.' Journal of English for Academic Purposes 6, 319-335.

Goodson, P. (2017) Becoming an Academic Writer. 50 Exercises for Paced, Productive and Powerful Writing. $2^{\text {nd }}$ ed. Thousand Oaks, California: Sage.

Gunn, C., Hearne, S. and Sibthorpe, J. (2011) 'Right from the start: A rationale for embedding academic literacy skills in university courses.' Journal of University Teaching \& Learning Practice 8(1). Retrieved from: https://ro.uow.edu.au/jutlp/vol8/ iss $1 / 6$.

Halliday, M. A. K. and Matthiessen, C. M. I. M. (2014) Halliday's Introduction to Functional Grammar. $4^{\text {th }}$ ed. London and New York: Routledge.

Hamp-Lyons, L. (2001) 'English for academic purposes.' In: Cater, R. and Nunan, D. (eds) The Cambridge Guide to Teaching English to Speakers of Other Languages. Cambridge: Cambridge University Press.

Hamp-Lyons, L. and Heasley, B. (2006) Study Writing. A Course in Writing Skills for Academic Purposes. $2^{\text {nd }}$ ed. Cambridge: Cambridge University Press.

Hannay, M. (2007) 'Patterns of multiple theme and their role in developing English writing skills.' In: Lavid, J., Hidalgo Downing, R. and Butler, C. (eds) Functional Perspectives on Grammar and Discourse: In Honour of Angela Downing. Amsterdam: John Benjamins. 257-278.

Hawes, T. and Thomas, S. (2012) 'Theme choice in EAP and media language.' Journal of English for Academic Purposes 11, 175-183.

Howell, W. S. (1979) 'Theoretical directions for intercultural communication.' In: Asanti, M. K., Newmark, E. and Black, C. A. (eds) Handbook of Intercultural Communication. Newbury Park, California: Sage. 23-41.

Howell, W. S. (1982) The Emphatic Communicator. Belmont, CA: Wadsworth.

Huang, L. (2010) 'Seeing eye to eye? The academic writing needs of graduate and undergraduate students from students' and instructors' perspective.' Language Teaching Research 14 (4), 517-539.

Hůlková, I., Dontcheva-Navratilova, O., Jančaříková, R. and Schmied, J. (2019) 'Intercultural variation in academic discourse: Theme zones and the build-up of coherence in research articles.' Topics in Linguistics 20(2), 33-53.

Hutchinson, R. and Waters, A. (1987) English for Specific Purposes: A Learning-centred Approach. Cambridge: Cambridge University Press.

Huhta, M., Vogt, K., Johnson, E. and Tulkki, H. (2013) Needs Analysis for Language Course Design. A Holistic Approach to ESP. Cambridge: Cambridge University Press.

Hyland, K. (2016) 'Methods and methodologies in second language writing research.' System 59, 116-125.

Hyland, K. (2004) Genre and Second Language Writing. Ann Arbor: University of Michigan Press.

Hyland, K. (1997) 'Is EAP necessary? A survey of Hong Kong undergraduates.' Asian Journal of English Language Teaching 7, 77-99.

Ismail, N., Hussin, S. and Darus, S. (2012) 'ESL students' attitude, learning problems, and needs for online writing.' GEMA Online Journal of Language Studies 12(4), 1089-1107.

Kilgarriff, A., Rychlý, P., Smrz, P. and Tugwell, D. (2004) 'The Sketch Engine.' In: Proc Eleventh EURALEX International Congress. Lorient, France.

Link, S. (2018) 'Scaling up graduate writing workshops: From needs assessment to teaching practices.' Journal of Writing Research 10(2), 357-399. 


\section{Renata Jančaňíková, Renata Povolná, Olga Dontcheva-Navratilova, Světlana Hanušová, Martin NĚMec}

Long, M. H. (2005) 'Methodological issues in learner needs analysis.' In: Long, M. H. (ed.) Second Language Needs Analysis. Cambridge: Cambridge University press. 19-76.

Paltridge, B., Harbon, S., Hirsch, D., Shen, H., Stevenson, M., Phakiti, A. and Woodrow, L. (2009) Teaching Academic Writing. An Introduction for Teachers of Second Language Writers. Ann Arbor: The University of Michigan Press.

Paltridge, B. and Starfield, S. (2007) Thesis and Dissertation Writing in a Second Language. Oxon/New York: Routledge.

Poole, R. (2016) 'A corpus-aided approach for the teaching and learning of rhetoric in an undergraduate composition course for L2 writers.' Journal of English for Academic Purposes 21, 99-109.

Povolná, R. (2010) 'Can non-native speakers of English use contrastive discourse markers correctly when writing academic tetxs?' In: Malá, M. and Šaldová, P. (eds) ... for thy speech bewrayeth thee. A Festschrift for Libuše Dušková. Praha: Univerzita Karlova v Praze, Filozofická fakulta. 209-231.

Povolná, R. (2012) 'Cross-cultural differences in the use of discourse markers by Czech and German students of English in the genre of master's theses.' In: Berkenkotter, C., Bhatia, V. and Gotti, M. (eds) Insights into Academic Genres. Bern: Peter Lang. 329-351.

Schmied, J. (2011) 'Academic writing in Europe: A survey of approaches and problems.' In: Schmied, J. (ed.) Academic Writing in Europe: Empirical Perspectives. REAL Studies 5. Göttingen: Cuvillier Verlag. 1-22.

Schmied, J. (2013) 'English for academic purposes: Contrastive perspectives in the curriculum.' In: Haase, C. and Schmied, J. (eds) English for Academic Purposes: Practical and Theoretical Approaches. Research in English and Applied Linguistics. REAL Studies 7. Göttingen: Cuvillier Verlag. 19-40.

Swales, J. (2004) Research Genres. Explorations and Applications. Cambridge: Cambridge University Press.

Thompson, G. (2014) Introducing Functional Grammar. $3^{\text {rd }}$ ed. London and New York: Routledge.

Vogel, R. (2013) 'Sentence adverbials in academic texts: Perspectives of native vs. non-native writers.' In: Haase, C. and Schmied, J. (eds) English for Academic Purposes: Practical and Theoretical Approaches. Research in English and Applied Linguistics. REAL Studies 7. Göttingen: Cuvillier Verlag. 81-93.

Wagner, S. (2011) 'Concessives and contrastives in student writing: L1, L2 and genre differences.' In: Schmied, J. (ed.) Academic Writing in Europe: Empirical Perspectives. REAL Studies 5. Göttingen: Cuvillier Verlag. 23-49.

Wei, J. (2016) 'Thematic choice in Chinese college students' English essays.' English for Specific Purposes 41, 50-67.

Wisker, G. (2012) The Good Supervisor. Supervising Postgraduate and Undergraduate Research for Doctoral Theses and Dissertations. $2^{\text {nd }}$ ed. Basingstoke: Palgrave Macmillan.

Xudong, D., Cheng, L. K., Varaprasad, C. and Leng, L. M. (2014) 'Academic writing development of ESL/EFL graduate students in NUS.' Reflections on English Language Teaching 9(2), 119-138. 
Renata Jančaříková is Assistant Professor at Masaryk University, Brno. She specializes in British newspaper discourse with focus on crime news and the social aspects of crime news language, and academic writing and the teaching of academic writing at tertiary level. Apart from a number of journal articles, she is the author of Victims vs Killers in the British Press: Naming Strategies in Murder Reports (2014) and co-authored the volume Coherence and Cohesion in English Discourse (2012).

Address: Renata Jančaříková, Department of English Language and Literature, Faculty of Education, Masaryk University, Pořičí 9, Brno 603 00, Czech Republic. [e-mail: jancarikova@ped.muni.cz]

Renata Povolná is Associate Professor of English Linguistics at Masaryk University, Brno. Her research interests lie in the area of discourse analysis, pragmatics and conversation analysis, concentrating mainly on academic and technical discourse. She has published many articles and the books Spatial and Temporal Adverbials in English Authentic Face-to-Face Conversation (2003) and Interactive Discourse Markers in Spoken English (2010) and co-authored the volume Cohesion and Coherence in English Discourse (2012).

Address: Renata Povolná, Department of English Language and Literature, Faculty of Education, Masaryk University, Poříčí 9, 603 00, Brno, Czech Republic. [e-mail: povolna@ped.muni.cz]

Olga Dontcheva-Navratilova is Associate Professor of English Linguistics at Masaryk University, Brno. She specializes in discourse analysis, genre analysis, stylistics and pragmatics, with a focus on academic and political discourse. She has published many articles and the books Analysing Genre: The Colony Text of UNESCO Resolutions (2009) and Coherence in Political Speeches (2011) and co-authored the volume Cohesion and Coherence in English Discourse (2012).

Address: Olga Dontcheva-Navratilova, Department of English Language and Literature, Faculty of Education, Masaryk University, Poříčí 9, 603 00, Brno, Czech Republic. [e-mail: navratilova@ped.muni.cz]

Světlana Hanušová is Associate Professor at Masaryk University, Brno. She specializes in foreign language didactics. Her research interests include foreign language teaching and learning, English language teacher education and course design in foreign language teaching. She is the main author of the 
monograph Chtěji zůstat nebo odejit? Začinajicí učitelé v českých základních školách [Do they want to stay or leave? Novice teachers at Czech primary and lower-secondary schools] (2017).

Address: Světlana Hanušová, Department of English Language and Literature, Faculty of Education, Masaryk University, Poříći 9, Brno 603 00, Czech Republic. [e-mail: hanusova@ped.muni.cz]

Martin Němec is Assistant Professor at Masaryk University, Brno. He specializes in applied linguistics with a focus on English/Czech translations and their development and reflections in time. He is also presenting and publishing articles about the educational value of didactic translation in EFL.

Address: Martin Němec, Department of English Language and Literature, Faculty of Education, Masaryk University, Poříći 9, Brno 603 00, Czech Republic. [e-mail: nemecm@ped.muni.cz] 